\title{
Ovarian Dynamic in Ongole Grade Cattle after GnRH Injection in Ovsynch Protocol Based on Progesterone Device
}

\author{
M. Imron ${ }^{\mathrm{a}, *}$, I. Supriatna ${ }^{\mathrm{b}}$, Amrozi $^{\mathrm{b}}$, \& M. A. Setiadi ${ }^{\mathrm{b}}$ \\ ${ }^{a}$ National Livestock of Embryo Center Cipelang \\ PO Box 485 Bogor, Indonesia \\ ${ }^{\mathrm{b}}$ Faculty of Veterinary Medicine, Bogor Agricultural University \\ Jalan Agatis, Kampus IPB Darmaga, Bogor 16680, Indonesia \\ (Received 08-04-2015; Reviewed 23-04-2015; Accepted 04-06-2015)
}

\begin{abstract}
PO cattle have weaknesses to show clear estrus signs which cause difficulty in artificial insemination implementation. The present study was designed to obtain ovarian dynamic as effect of GnRH injection in ovsynch protocol based on progesterone intravaginal device. Heifers (18) and cows (n= 12) were allocated to one of three groups. Cuemate-PGF2 $\alpha$ (CP) group inserted with a Cuemate on day 0-7 and injected with prostaglandin on day 7. Cuemate-PGF2 $\alpha$-GnRH (CPG) group was treated as CP group with the addition of GnRH injection on day 9. GnRH-Cuemate-PGF2 $\alpha$-GnRH (GCPG) group was treated as CPG group with addition of $\mathrm{GnRH}$ injection on day 0 . Ultrasonography was performed on days 0-3, day 7 until ovulation and 7 days after ovulation. Percentage of ovulation synchronization increased significantly $(\mathrm{P}<0.01)$ between $\mathrm{CP}, \mathrm{CPG}$, and GCPG, respectively, both in heifers $(16 \%, 50 \%$, and $85 \%$, respectively) and cows $(0 \%, 60 \%$, and $100 \%$, respectively), on day 11 . Preovulatory follicle diameters between CP, CPG, and GCPG treatments were not different significantly both in heifers $(11.9 \pm 0.5,11.9 \pm 0.5$, and $12.1 \pm 0.6 \mathrm{~mm}$, respectively) and cows $(11.7 \pm 0.4,11.8 \pm 0.7$, and $11.1 \pm 0.6 \mathrm{~mm}$, respectively). This study concluded that GCPG protocol increased the synchrony of ovulation rate both in cows and heifers, without affecting the follicle preovulatory and CL diameters.
\end{abstract}

Key words: ovarian dynamic, GnRH, ovsych, PO Cattle

\section{ABSTRAK}

Sapi PO memiliki kelemahan dalam menunjukkan tanda tanda berahi yang jelas sehingga menyulitkan untuk pelaksanaan inseminasi buatan. Penelitian ini dilakukan untuk mendapatkan informasi dinamika ovarium pada sapi PO sebagai respons terhadap penyuntikan gonadorelin (GnRH) dalam protokol ovsynch berbasis preparat progesteron intravaginal. Sapi dara $(n=18)$ dan induk $(n=$ 12) dibagi secara acak menjadi tiga kelompok. Kelompok satu, Cuemate-PGF2 $\alpha$ (CP), diberi perlakuan dengan memasukkan cuemate ke dalam vagina pada hari ke-0-7 dan disuntik prostaglandin pada hari ke-7. Kelompok dua, Cuemate-PGF2 $\alpha$-GnRH (CPG), sama dengan kelompok satu, tapi dengan penambahan penyuntikan GnRH pada hari ke-9. Kelompok tiga, GnRH-Cuemate-PGF2 $\alpha$ GnRH (GCPG), sama dengan kelompok dua, tapi dengan penambahan penyuntikan GnRH pada hari ke-0. USG dilakukan pada hari ke-0-3, 7 sampai ovulasi dan 7 hari setelah ovulasi. Persentase sinkronisasi ovulasi meningkat sangat nyata $(\mathrm{P}<0.01)$ berturut-turut pada $\mathrm{CP}, \mathrm{CPG}$, dan GCPG pada dara $(16 \%, 50 \%$, dan $85 \%)$ maupun induk $(0 \%, 60 \%$, dan $100 \%)$, pada hari ke-11. Diameter folikel praovulatori tidak berbeda nyata antara perlakuan CP, CPG, dan GCPG pada dara $(11.9 \pm 0.5,11.9 \pm 0.5$, dan $12.1 \pm 0.6 \mathrm{~mm}$ ) maupun pada induk $(11.7 \pm 0.4,11.8 \pm 0.7$, dan $11.1 \pm 0.6 \mathrm{~mm})$. Penelitian ini menyimpulkan bahwa protokol GCPG meningkatkan persentase sinkronisasi ovulasi baik pada dara maupun induk tanpa mempengaruhi diameter folikel praovulatori maupun korpus luteum.

Kata kunci: dinamika ovaria, GnRH, ovsych, Sapi PO

*Corresponding author:

E-mail: hibbanie@gmail.com; setiadi03@yahoo.com 


\section{INTRODUCTION}

Ongole cattle (Bos indicus) are well-adapted breeds to the tropical climate. They have high resistance to the external parasites and well adapted to the low quality of feed (Gaur et al., 2002). However, Ongole cattle is reported to have shorter period of estrous than Bos taurus breed and this breed is often does not show clear signs of estrous, and the estrous mostly start in the evening (Behl et al., 2010). Those weaknesses of reproductive signs cause difficulty in implementing artificial insemination (AI) (Sartori \& Baros, 2011; Acevedo et al., 2007).

The Ongole cattle were introduced to Indonesia started at early of $19^{\text {th }}$ century and they were bred mainly with local Java breed cattle to produce cross breed beef cattle known as Ongole Grade cattle (Diwyanto, 2008). The Ongole Grade cattle were reported to have long days open caused by estrus detection problems which resulted in long calving interval (Astuti, 2004; Nuryadi \& Wahjuningsih, 2011). Therefore it is necessary to establish an appropriate estrous synchronization protocol to optimize estrous detection in Ongole Grade cattle.

Recently, the estrous synchronization protocols are focused on the controlling of follicular waves to synchronize ovulation (Ovsych protocol) by combining gonadotropin releasing hormone $(\mathrm{GnRH})$, progesterone device, and PGF2 $\alpha$ treatments to support fixed time artificial insemination (FTAI) program (Sahu et al., 2014; Kasimanickam et al., 2014). A single injection of GnRH causes a release of $\mathrm{LH}$, which leads to synchronized ovulation or luteinization of most large dominant follicles. Consequently, a new follicular wave is initiated in all cows within 2 to $3 \mathrm{~d}$ of $\mathrm{GnRH}$ administration (Patterson et al., 2003). While progesterone supplementation between GnRH and PGF2 $\alpha$ injections improves synchronization and is useful to prevent premature estrus, LH surge, and ovulation in cattle without prolonging a AI program (Sá Filho et al., 2010; Whittier et al., 2010; Peterson et al., 2011).

Several methods of ovulation synchronization based on GnRH and progesterone device produce tight synchronization for AI application and resulted in an acceptable pregnancy rate both for B. taurus (Azevedo et al., 2014; Kim et al., 2005) and B. indicus (Martins et al., 2014; Meneghetti et al., 2009). However, more observations are required whether those protocols will be suitable for Ongole Grade cattle. The aim of the present study was to obtain information of ovarian dynamic include follicular wave development, ovulation rate, preovulatory follicle diameter, and subsequent CL diameter in heifer and cow as effect of GnRH in ovsynch protocol based on progesterone intravaginal device.

\section{MATERIALS AND METHODS}

\section{Animals}

Ongole Grade cattle cows $(n=12)$ and heifers $(n=$ 18) were used in this study. The cows were between 5 and 6 years of age with body weight ranging from 375 to $450 \mathrm{~kg}$, meanwhile the heifers were between 2.5 and 3.5 years of age with body weight ranging from 325 to 375 $\mathrm{kg}$. Body condition scores (BCS) of cattle were between 2.7 and 3.2 based on 0 to 5 score basis point, had normal reproductive organ and estrous cycle. They were maintained in the barn, feed daily with 30 to $40 \mathrm{~kg}$ chopped grass and 2 to $3 \mathrm{~kg}$ concentrate ration for each cattle. Treated cattle which were used for more than once per treatment were given 2 mo rest time between treatments to eliminate the influence of previous treatment. Experimental protocols in this study were approved by Ethical Clearance Commission, Faculty of Veterinary Medicine, Bogor Agricultural University (Certificate No: 001/KEH/SKE/VI/2014).

\section{Treatments}

Cattle were assigned randomly to one of three treatments. All experimental cattle in each group were inserted with an intravaginal progesterone device (Cuemate, containing $1.56 \mathrm{mg}$ progesterone in two silicon pods, Bioniche Animal Health, Asia Pty, Australia) on day 0 for $7 \mathrm{~d}$. Cuemate was placed into the vagina by using a lubricated applicator. Prostaglandin hormone was given in a single i.m. injection (Prostavet C, 5 $\mathrm{mg}$ of etiproston per $2 \mathrm{~mL}$ of solution; Virbac Animal Health, France) on day 7, just before Cuemate removal. Cuemate-PGF2 $\alpha-\mathrm{GnRH}$ (CPG) group was given an injection of $100 \mu \mathrm{g}$ of GnRH (Fertagyl, containing 1000 $\mu \mathrm{g}$ gonadorelin diacetate tetrahydrate in $20 \mathrm{~mL}$ solution, Intervet Schering-Plough Animal Health, Germany) on day 9. GnRH-Cuemate-PGF $2 \alpha-\mathrm{GnRH}$ (GCPG) group was given a $100 \mu \mathrm{g}$ of $\mathrm{GnRH}$ injection i.m. on day 0 and day 9. Cuemate-PGF2 $\alpha(C P)$ group was not received any additional treatments (Figure 1).

\section{Ovarian Observation}

Ovarian observations including measurement of the follicle and CL diameter were done by ultrasound

CP

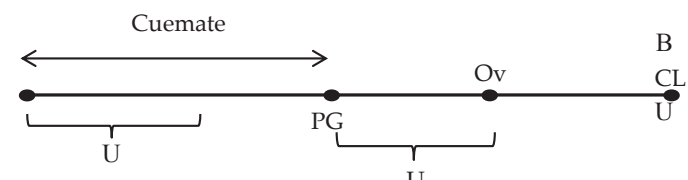

CPG

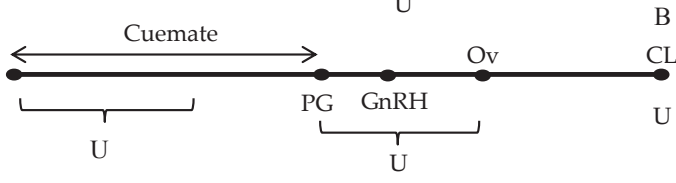

GCPG

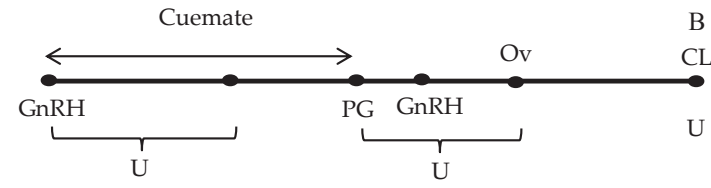

Days

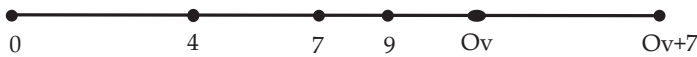

Figure 1. Treatments schedule of the CP, CPG, and GCPG. PGF2 $\alpha$ (PG) was administered just after Cuemate removal. USG scanning (U) was done daily from D0 to D2, D7 until ovulation occur (Ov) and on 7 days after ovulation $(\mathrm{CL})$. 
(USG) equipped with goggle glass (EasyScan Lite, Germany), scanned with 4-8 $\mathrm{MHz}$ dynamic frequency probe. USG was connected to a computer for data recording in video format. The response of the treatment on ovarian dynamics was evaluated by measuring the diameter of the largest dominant follicle and corpus luteum (CL) using Microsoft image tool.

The ovulation responses of the dominant follicle to treatment between day 0 and 7 were evaluated. The day of a follicular wave emergence was identified as a new wave if the developments of diameter follicle reached 4 mm or greater (Sahu et al., 2014). The previous day will be considered as the first day if the dominant follicle was not detected until it reached the diameter of 6 or 7 $\mathrm{mm}$. Ovulation was determined as the disappearance of a previously identified as dominant follicle followed by the development of a CL. Observations of estrous sign were made visually in the morning and afternoon from day one to six after PGF2 $\alpha$ injection.

\section{Progesterone Hormone Assay}

Progesterone was measured by enzyme linked immuno assay (ELISA) to determine the presence of functional CL. Blood samples were collected via coccygeal vein puncture on day 7 after detected ovulation. Blood was collected in $5 \mathrm{~mL}$ plain vacutainer and allowed to clot for $24 \mathrm{~h}$. Blood serum was separated by centrifugation at $500 \mathrm{G}$ for $10 \mathrm{~min}$ at room temperature and frozen at $-20{ }^{\circ} \mathrm{C}$ until hormone assay.

\section{Statistical Analysis}

The study was conducted by completely randomized design. Data were analyzed with a statistical software program (IBM SPSS Statistic version 21 for Windows). The influence of age and interval to new wave emergence in each treatment was tested by Independent-Sample $\mathrm{T}$ Test. Differences in the mean of follicle diameters, CL diameters, and progesterone concentrations between treatments were analyzed by one-way ANOVA with Tukey's multiple comparison tests using post hoc where ANOVA was significant. A P-value of 0.05 was considered significant. The relationship between preovulatory follicle diameter and CL diameter were tested by Pearson correlation test. The proportion of cattle with ovulation and new follicular wave emergence was compared by the Chi-squared Test.

\section{RESULTS AND DISCUSSION}

The effectiveness of the ovulation synchronization program is determined by the ability of the program to generate a thigh synchronized ovulation thus allowing AI could be accomplished at certain time. The present study demonstrated that GnRH injection on day 0 (GCPG group) caused ovulation both for heifer and cow $(22 \%$ and $50 \%$, respectively), meanwhile no follicle ovulation was observed in CP and CPG groups which had no GnRH treatment at day 0 (Table 1). Other studies reported that administration of $\mathrm{GnRH}$ irrespective of estrous cycle stages resulted in ovulation rate of $27 \%$ -
45\% (Sahu et al., 2014; Giordano et al., 2013; Lima et al., 2011). Minimum ovulated follicles diameter in response to GnRH treatment on day 0 (first GnRH) in present study was $9 \mathrm{~mm}$, smaller than that reported by Sartori et al. (2001) who had observed previously in Nellor cattle (10 mm). The difference of follicle development may be influenced by breed.

The percentages of heifer and cow which had new follicular wave were higher in GCPG group (78\% and $75 \%)$ than CP (50\% and 57\%), and CPG groups (67\% and $60 \%$ ), respectively (Table 1). These results indicated that first GnRH injection tended to increase the development of new follicular wave emergence. This finding was in line with the data from Sahu et al. (2014) who reported new follicular wave in $80 \%$ of dairy cattle treated with first $\mathrm{GnRH}$ was higher compared with $57 \%$ in treatment without first GnRH. Furthermore, GCPG group which treated with first GnRH had shorter interval to follicular wave emergence $(3.28 \pm 0.76$ and $3.50 \pm 0.58)$ than without first GnRH treatment (CP and CPG) both in heifers $(4.43 \pm 0.97$ and $4.64 \pm 1.07)$ and cows $(4.37 \pm 1.10$ and $4.0 \pm 0.69)$, respectively. Follicular wave emergence is initiated by a surge of FSH, meanwhile estradiol produced by dominant follicle has a major inhibitory action on FSH release from pituitary gland (Bo et al., 1995). Adam et al. (2008) reported that if a dominant follicle was removed by follicular ablation or other mechanism, a FSH surge would begin within $12 \mathrm{~h}$ which resulted in emergence of a new follicular wave within next $24 \mathrm{~h}$. This finding may explain the treatment with first GnRH (GCPG) had more follicular wave emergence and occurred earlier than group without first GnRH (CP and CPG).

Changes in the mean of the dominant follicle diameter did not differ between CP, CPG, and GCPG groups on days 0-10 (Figure 2). However, if the cattle which had ovulating follicle in response to first $\mathrm{GnRH}$ injection in GCPG group were separated as one group (ovulation group), the mean diameter on days 0-10 of this group would be significantly different compared with $\mathrm{CP}, \mathrm{CPG}$, and GCPG groups, especially on days 7 and $9(\mathrm{P}<0.05)$ (Figure 2). Ovulation group also had tendency to have smaller preovulatory follicle diameter

Table 1. Ovarian dynamics in groups treated with first GnRH (GCPG group) and without first $\mathrm{GnRH}$ (CP and CPG groups) for heifer and cow

\begin{tabular}{llcccc}
\hline Treatment & Parity & $\mathrm{n}$ & $\begin{array}{c}\text { Ovulation* } \\
(\%)\end{array}$ & $\begin{array}{c}\text { New follicle } \\
\text { wave }(\%)\end{array}$ & $\begin{array}{c}\text { Follicle } \\
\text { emergence } \\
\text { (day) }\end{array}$ \\
\hline CP & Heifer & 6 & $0^{\mathrm{a}}$ & $3(50)$ & $4.43 \pm 0.97$ \\
& Cow & 7 & $0^{\mathrm{a}}$ & $4(57)$ & $4.64 \pm 1.07$ \\
CPG & Heifer & 6 & $0^{\mathrm{a}}$ & $4(67)$ & $4.37 \pm 1.10$ \\
& Cow & 5 & $0^{\mathrm{a}}$ & $3(60)$ & $4.00 \pm 0.69$ \\
GCPG & Heifer & 9 & $2(22)^{\mathrm{b}}$ & $7(78)$ & $3.38 \pm 0.76$ \\
& Cow & 4 & $2(50)^{\mathrm{b}}$ & $3(75)$ & $3.50 \pm 0.58$ \\
\hline
\end{tabular}

Note: $\mathrm{CP}=$ Cuemate-PGF2 $\alpha, \mathrm{CPG}=$ Cuemate-PGF2 $\alpha-\mathrm{GnRH}, \mathrm{GCPG}=$ $\mathrm{GnRH}-\mathrm{Cuemate-PGF2} \alpha-\mathrm{GnRH}$. First GnRH was injected at day 0 . Means in the same column with different superscripts differ significantly $\left.(\mathrm{P}<0.05) .{ }^{*}\right)$ ovulated after the start of the treatment (Day 2-3). 


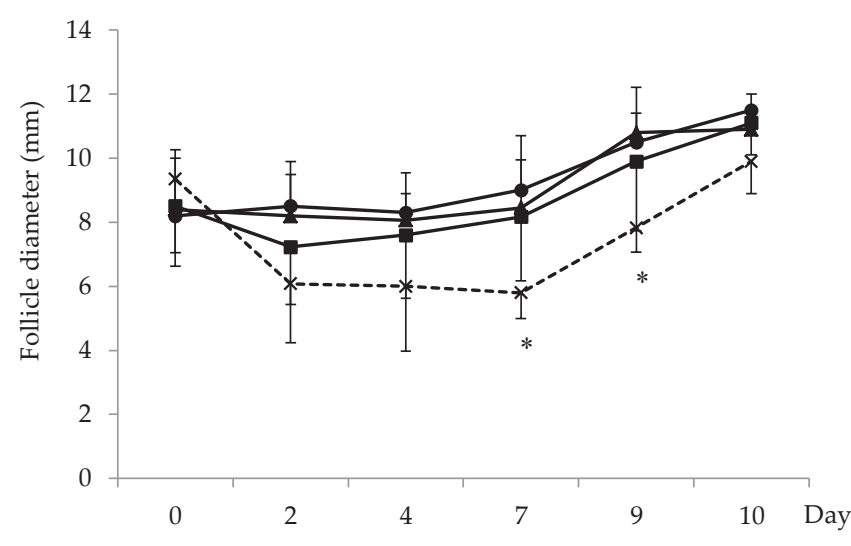

Figure 2. The mean changes of dominant follicle diameter from days 0 to 10 in Cuemate-PGF2 $\alpha$ (CP) (- $\mathbf{\Delta}$-), Cuemate-

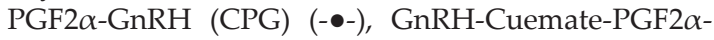
GnRH (GCPG) (-m-), and ovulation (-x-) groups. Ovulation group is GCPG group which have ovulating follicle after first GnRH injection. *)Mean of dominant follicle diameter in ovulation group significantly different with $\mathrm{CP}, \mathrm{CPG}$, and GCPG groups $(\mathrm{P}<0.05)$.

on day $10(\mathrm{P}=0.132)$ than $\mathrm{CP}, \mathrm{CPG}$, and GCPG groups. This finding is consistent with the data reported by Keskin et al. (2010). Cattle which had ovulating follicle in response to the first $\mathrm{GnRH}$ injection would form accessories CL which might increase the concentration of blood progesterone. Furthermore, Kim et al. (2005) reported that progesterone increased linearly in the first GnRH-ovulated group on day 4-7, which appeared to be associated with the ovulation of the dominant follicle that was present at the time of first GnRH injection, and subsequent CL formation during CIDR insertion period. Junior et al. (2010) reported that a greater peripheral of progesterone concentration was associated with a lower frequency of LH pulses, and consequently decreased peripheral estradiol concentrations and rate of dominant follicle growth. These mechanisms might involve in the processes that caused the ovulation group had smaller preovulatory follicle than non-ovulation group.

The GnRH injection at random stages of the cycle increases the probability of ovulation (Twagiramungu et al., 1995). In the present study, the percentage of ovulation synchronization increased significantly between $\mathrm{CP}$ (without GnRH injection), CPG (GnRH injection on day 9), and GCPG (GnRH injection on day 0 and 9) both in heifers $(16 \%, 50 \%$, and $85 \%, \mathrm{P}<0.01)$ and cows $(0 \%, 60 \%$, and $100 \%, \mathrm{P}<0.01$ ), respectively on day 11 (solid bar, Figure 3). Apparently, treatment with GnRH injection increased and synchronized ovulation rate in beef cattle, which was consistent with finding by Kasimanickam et al. (2012) who reported that GnRH injection improved synchrony of the estrous cycle by initiating of new follicular wave, developing of a follicle under high systemic progesterone concentrations, and limiting the follicle dominance duration, and assuring the presence of an ovulatory follicle at the time of AI.

Treatment with GnRH injection on day 0 and day 9 (GCPG group) provided higher synchronization in ovulation rate compared with $\mathrm{CP}$ treatment and CPG.
This finding was in agreement with previous studies reported that treatments with combination of double injections of GnRH, PGF2 $\alpha$ and progesterone device resulted ovulation synchronization rate between $86 \%$ 92\% (Kasimanickam et al., 2014; Sahu et al., 2014). $\mathrm{GnRH}$ treatments on day 0 and day 9 were apparently capable of synchronizing follicular wave emergence regardless of the stage of follicular development at the time of treatment (Souza et al., 2011). However, the low intensity and duration of estrous behavior resulted in satisfactory conception rates with ovsyinch protocol using double injection of GnRH (Lee et al. 2013).

Interestingly, ovulation rate of heifer in the present study tended to occur earlier than cows in $\mathrm{CP}, \mathrm{CPG}$, and GCPG groups (16\%, 49\%, and 14\%, respectively) (Figure 3). This finding was supported by Sartori et al. (2001) who reported that cow ovulated later after luteolysis than heifer. Meanwhile, Bo et al. (2003) reported that $28.9 \%$ of the Ovsynch-treated B. indicus heifers exhibited natural estrus between $\mathrm{GnRH}$ injection and the assigned time of FTAI. In the present study, the average number of large follicles in the ovaries during most days of the cycle tended to be higher in heifer than in cow in $\mathrm{CP}$, CPG, and GCPG groups (unpublished data), suggesting that follicle in heifer might grow faster and tended to ovulate earlier than in cow.

Mostly heifers and cows had a CL or in luteal phase at initial insertion of progesterone device at day 0 , irrespective of age and its capability to produce proges-

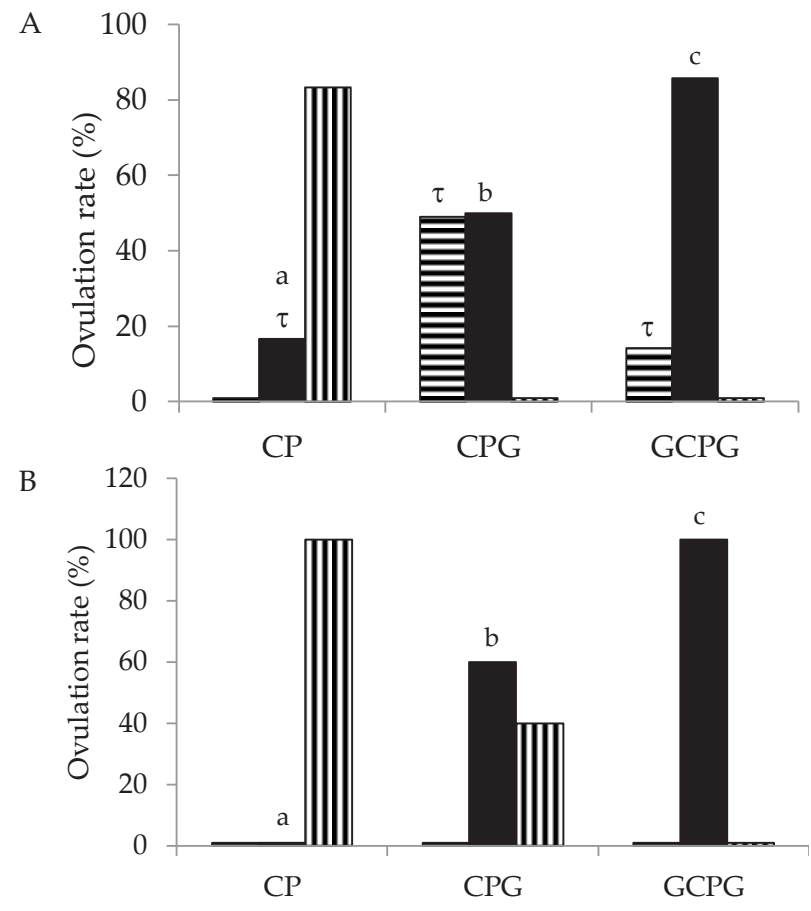

Figure 3. Distribution of percentage ovulation after PGF2 injection at different days interval in Cuemate-PGF2 $\alpha(\mathrm{CP})$, Cuemate-PGF $2 \alpha-G n R H \quad(C P G), \quad$ GnRH-CuematePGF2 $\alpha-G n R H$ (GCPG) groups for heifer (A) and cow

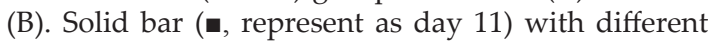
superscripts differ significantly $(\mathrm{P}<0.05)$; $\mathbf{\Xi}=$ day $<11$; $\mathbf{D}=$ day $>11$. $\tau$ : indicate ovulation occur earlier in heifer than cow. 
terone, in $\mathrm{CP}$ treatment (83\% and $100 \%$ ), CPG treatment $(66.6 \%$ and $100 \%)$, and GCPG treatment $(77.7 \%$ and $75 \%)$, respectively. If treatment was initiated when animals in the luteal phase, implantation of progesterone device would strengthen the influence of indigenous progesterone produced by luteal cell to prevent ovulation, as Whittier et al. (2010) reported that progesterone was useful to inhibit premature estrus, LH surge, and ovulation. Whereas if treatment was initiated when the animals were in the follicular phase, progesterone device would release exogenous progesterone and created an artificial mid-luteal phase environment in all heifers or cows that served to prevent premature estrus and ovulation (Bo et al. 2003). But, the administration of first $\mathrm{GnRH}$ injection in the treatment GCPG would trigger ovulation or luteinization of any existing dominant follicle and this would be followed by the development of a new follicular wave emergence.

Precision of ovulation synchronization depends on controlling the corpus luteum and follicular development. Injections of PGF $2 \alpha$ may induce luteolysis, but not the ovulation (Akbarabadi et al., 2014). Timing of ovulation was influenced by the diameter of the dominant follicle at the time of injection of PGF $2 \alpha$ (Wiltbank \& Pursley, 2014). The dominant follicle will continue to grow and ovulate whenever it reaches ovulatory size, even though the CL will undergo luteolysis in response to PGF $2 \alpha$ injection. Therefore, it was plausible that the time of ovulation in $\mathrm{CP}$ group was more synchronize than CPG and GCPG group since no control of follicular development and ovulation was applied through $\mathrm{GnRH}$ administration.

In the present study, estrus sign that was clinically observed ranged from $43 \%-60 \%$ of populations both in heifer and cow (Table 2). Previous studies reported that estrous was observed $50 \%$ in Nellor heifer (Sartori \& Baros, 2011), 58\% in Brahman cow (Adriani et al., 2009), and $80 \%$ in Ongole cattle (Ramana et al., 2013). Furthermore, Galina et al. (2007) reported that although estrus was detected during the early morning and evening hours, estrus detection might not have been intensive enough because visual signs of estrus could be difficult to detect in cattle of $B$. indicus. Likelihood the Ongole Grade cattle showed estrus sign at night or silent heat since few traces of dried mucus observed in some of Ongole Grade cattle in the morning.

In agreement with Sartori \& Barros (2011), other possible reason for the lack of estrus sign beside an inherent breed effect was low environment temperature since this study located about $900 \mathrm{~m}$ above the sea level with ambient temperature about 16 to $26{ }^{\circ} \mathrm{C}$. Low temperature could be a stress factor for Ongole Grade cattle as this breed had developed and well adapted to warmer tropical climate. Stressors affect reproductive functions through actions at the hypothalamus as well as impairing pituitary LH release induced by $\mathrm{GnRH}$ and will lead to reduced estradiol production by slower growing follicle (Etim et al., 2013). Cold stress might explain the lower rate of clinical estrus sign observed in Ongole Grade cattle in this study. No other studies have reported the effect of cold stress in reproduction status in Ongole Grade cattle or other tropical breed cattle.

Interestingly, two heifers on GCPG treatment did not ovulate after the second GnRH injection on day 9, but ovulation was on day 3 at the first GnRH injection. These heifers had accessory CL as subsequent development of ovulatory follicles in response to the first GnRH injection. There was a possibility that this accessory CL did not undergo luteolysis after PGF2 $\alpha$ injection on day 7 caused by a young age of CL (4 d). Any ovulation after the first GnRH injection would result in a newly formed CL that might be less likely to regress after a single PGF2 $\alpha$ injection (Kasimanickam et al., 2014). Large luteal cells originate from granulosa cells were more responsive to PGF and resulted in luteolysis than small luteal cells (Peterson et al., 2011). Apparently, accessory CL had more small luteal cells than large ones, so that PGF2 $\alpha$ treatment of beef heifers on day 7 did not markedly impair luteal function.

Preovulatory follicle diameter between CP, CPG, and GCPG treatments in this study were not different significantly in heifers $(11.9 \pm 0.5,11.9 \pm 0.5$, and $12.1 \pm 0.6$ $\mathrm{mm})$ and cows $(11.7 \pm 0.4,11.8 \pm 0.7$, and $11.1 \pm 0.6 \mathrm{~mm})$, respectively (Table 2). These findings were consistent with Sahu et al. (2014) who reported that preovulatory follicle in group without first GnRH injection revealed similar size to the group which received first $\mathrm{GnRH}$ injection in ovsynch protocol based on CIDR in dairy heifers. This might be mediated by the progesterone device that suppressed the dominant follicle during its growing phase.

CL diameters on day 7 after ovulation in Ongole Grade cattle were not different significantly between $\mathrm{CP}$, CPG, and GCPG treatments both in heifers $(17.7 \pm 0.8$, $16.9 \pm 0.6$, and $18.0 \pm 0.8 \mathrm{~mm})$ and cows $(17.9 \pm 1.9,17.1 \pm 1.2$, and $16.7 \pm 1.5 \mathrm{~mm}$ ), respectively (Table 2). Irrespective of our data, Ramana et al. (2013) reported that CL diameter

Table 2. Observation of estrus signs and ovarian dynamic of PO cattle treated with CP, CPG and GCPG for heifer and cow

\begin{tabular}{ccccccc}
\hline Groups & Parity & $\begin{array}{c}\text { Estrus sign } \\
(\%)\end{array}$ & $\begin{array}{c}\text { Total ovulation } \\
(\%)\end{array}$ & $\begin{array}{c}\text { Preovulatory follicle } \\
(\mathrm{mm})\end{array}$ & $\begin{array}{c}\text { CL } \\
(\mathrm{mm})\end{array}$ & $\begin{array}{c}\text { Progesteron } \\
(\mathrm{ng} / \mathrm{mL})\end{array}$ \\
\hline \multirow{2}{*}{ CP } & Heifer & $3(50)$ & $6(100)$ & $11.9 \pm 0.5$ & $17.7 \pm 0.8$ & $4.06 \pm 1.37$ \\
& Cow & $3(43)$ & $7(100)$ & $11.7 \pm 0.4$ & $17.9 \pm 1.9$ & $3.65 \pm 1.96$ \\
\multirow{2}{*}{ CPG } & Heifer & $3(50)$ & $6(100)$ & $11.9 \pm 0.5$ & $16.9 \pm 0.6$ & $4.48 \pm 2.08$ \\
& Cow & $3(60)$ & $5(100)$ & $11.8 \pm 0.7$ & $17.1 \pm 1.2$ & $4.26 \pm 1.36$ \\
\multirow{2}{*}{ GCPG } & Heifer & $4(44)$ & $7(78)$ & $12.1 \pm 0.6$ & $18.0 \pm 0.8$ & $4.12 \pm 1.11$ \\
& Cow & $2(50)$ & $4(100)$ & $11.1 \pm 0.6$ & $16.7 \pm 1.5$ & $3.92 \pm 1.26$ \\
\hline
\end{tabular}

Note: $\mathrm{CP}=$ Cuemate-PGF2 $\alpha, \mathrm{CPG}=$ Cuemate-PGF2 $\alpha-\mathrm{GnRH}, \mathrm{GCPG}=\mathrm{GnRH}-\mathrm{Cuemate}-\mathrm{PGF} 2 \alpha-\mathrm{GnRH}, \mathrm{CL}=\mathrm{corpus}$ luteum. 
on day 10 following the induced estrus of Ongole cattle was $16.5 \pm 0.30 \mathrm{~mm}$. In this study, we used a cross breed Ongole that might be contribute to the differences in the sizes of the CL diameters, compared with those in pure breed Ongole cattle. Preovulatory follicle diameter in this study had a positive correlation with diameter of CL (R2=0.45, P<0.01). Dadarwal et al. (2013) and Perez et al. (2009) also reported that the size of preovulatory follicle had a positive correlation with CL diameter and P4 concentrations during the subsequent diestrus. For every increase of $1 \mathrm{~mm}$ in follicle size, day $10 \mathrm{CL}$ weight would increase by $1.5 \mathrm{~g}$ (Field et al., 2012). Furthermore, blood progesterone concentrations on day 7 after ovulation were also not different significantly between $\mathrm{CP}, \mathrm{CPG}$, and GCPG treatments in heifers $(4.06 \pm 1.37$, $4.48 \pm 2.08$, and $4.12 \pm 1.11 \mathrm{ng} / \mathrm{mL}$ ) and cows $(3.65 \pm 1.96$, $4.26 \pm 1.36$, and $3.92 \pm 1.26$ ), respectively (Table 2). Sahu et al. (2014) reported that progesterone concentration $7 \mathrm{~d}$ after ovulation was 3-5 $\mathrm{ng} / \mathrm{mL}$ in Nellor cattle.

This study clearly indicated that the occurrence ovulation during the first $\mathrm{GnRH}$ injection on day 0 produced a synchronous follicular wave and increased synchrony of ovulatory follicle size at the time of PGF $2 \alpha$ treatment. In addition, the second GnRH treatment on day 9 induced a synchronized ovulation higher than without GnRH. Thus, it is clear that the first and second GnRH treatments of Ovsynch based for $7 \mathrm{~d}$ progesterone device insertion are essential for optimal synchronization of a preovulatory follicular wave and tightly-synchronized ovulation in both of heifer and cows of Ongole Grade cattle.

\section{CONCLUSION}

Protocol of GCPG increased the synchrony of ovulation rate both in cows and heifers without affecting the preovulatory follicle diameter and its subsequent CL diameter.

\section{ACKNOWLEDGEMENT}

This research was supported by Indonesian Ministry of Agricultural scholarship. The authors gratefully acknowledge the National Livestock of Embryo Center (BET Cipelang) for use of the cattle and facilitate the trial.

\section{REFERENCES}

Acevedo, N., C. S. Galina, A. Pulido, \& A. Orihuela. 2007. Dynamics in sexually active groups of Zebu cattle (Bos indicus) comparing two procedures for estrus induction. J. Vet. Behav. 2:5-9. http://dx.doi.org/10.1016/j.jveb.2006.12.001

Adams, G. P., R. Jaiswal, J. Singh, \& P. Malhi. 2008. Progress in understanding ovarian follicular dynamics in cattle. Theriogenology 69:72-80. http://dx.doi.org/10.1016/j.theriogenology.2007.09.026

Adriani, B. Rosadi, \& Depison. 2009. The application of follicle stimulating hormone and pregnant mare serum gonadotropin hormone for superovulation in Brahman cross cattle. Med. Pet. 32:163-170.

Akbarabadi, M. A., H. K. Shabankareh, A. Abdolmohammadi, \& M. H. Shahsavari. 2014. Effect of PGF2 $\alpha$ and GnRH on the reproductive performance of postpartum dairy cows subjected to synchronization of ovulation and timed artificial insemination during the warm or cold periods of the year. Theriogenology 82: 509-516. http://dx.doi. org/10.1016/j.theriogenology.2014.05.005

Astuti, M. 2004. Potensi dan keragaman sumberdaya genetik sapi Peranakan Ongole (PO). Wartazoa 14: 30-39.

Azevedo, C., I. Maia, N. Canada, \& J. Simões. 2014. Comparison of fertility, regular returns-to-estrus, and calving interval between Ovsynch and CO-synch+CIDR protocols in dairy cows. Theriogenology 82:910-914. http://dx.doi. org/10.1016/j.theriogenology.2014.07.006

Behl, R., J. Behl, \& B. K. Joshi. 2010. Heat tolerance mechanisms in cattle-status in zebu cattle: A review. Indian J. Anim. Sci. 80: 891-897

Bo, G. A., P. S. Baruselli, \& M. F. Mart. 2003. Pattern and manipulation of follicular development in Bos indicus cattle. Anim. Reprod. Sci.78:307-326. http://dx.doi.org/10.1016/ S0378-4320(03)00097-6

Bo, G. A., G. P. Adams, R. A. Pierson, \& R. J. Mapletoft. 1995. Exogenous control of follicular wave emergence in cattle. Theriogenology 43:31-40. http://dx.doi.org/10.1016/0093691X(94)00010-R

Dadarwal, D., R. J. Mapletoft, G. P. Adams, L. F. M. Pfeifer, C. Creelman, \& J. Singh. 2013. Effect of progesterone concentration and duration of proestrus on fertility in beef cattle after fixed-time artificial insemination. Theriogenology 79: 859-866. http://dx.doi.org/10.1016/j.theriogenology.2013.01.003

Diwyanto, K. 2008. Pemanfaatan sumber daya lokal dan Inovasi teknologi dalam mendukung Pengembangan sapi potong di Indonesia. Pengembangan Inovasi Pertanian 1: 173-188.

Etim, N. N., E. E. A. Offiong, M. D. Udo, M. E. Williams, \& E. I. Evans. 2013. Physiological relationship between stress and reproductive efficiency. Agric. Biol. J. N. Am. 4:600-604.

Fields, S. D., K. L. Gebhart, B. L. Perry, M. G. Gonda, C. L. Wright, R. C. Bott, \& G. A. Perry. 2012. Influence of standing estrus before an injection of GnRH during a beef cattle fixed-time AI protocol on LH release, subsequent concentrations of progesterone, and steriodogenic enzyme expression. Dom. Anim. Endo. 42: 11-19. http://dx.doi. org/10.1016/j.domaniend.2011.08.002

Giordano, J. O., M. C. Wiltbank, P. M. Fricke, S. Bas, R. Pawlisch, J. N. Guenther, \& A. B. Nascimento. 2013. Effect of increasing GnRH and PGF2 $\alpha$ dose during DoubleOvsynch on ovulatory response, luteal regression, and fertility of lactating dairy cows. Theriogenology. 80:773-783. http://dx.doi.org/10.1016/j.theriogenology.2013.07.003

Gaur, G. K., S. N. Kaushik, \& R. C. Garg. 2002. Ongole cattle status in India. Animal Genetic Resources Information 32: 27-33. http://dx.doi.org/10.1017/S1014233900001528

Galina, C. S. \& A. Oriheula. 2007. The Detection of estrus incattle raised under tropical conditions: What we know and what we need to know. Horm. Behav. 52: 32-38. http:// dx.doi.org/10.1016/j.yhbeh.2007.03.025

Junior, C. I., O. G. Sa Filho, R. F. G. Perez, F. H. S. Aono, M. L. Day, \& J. L. M. Vasconcelos. 2010. Reproductive performance of prepubertal Bos indicus herifer after progesteron-based treatments. Theriogenology 74:903-911. http:// dx.doi.org/10.1016/j.theriogenology.2010.04.015

Kasimanickam, R. K., P. Firth, G. M. Schuenemann, B. K. Whitlock, J. M. Gay, D. A. Mooe, J. B. Hall, \& W. D. Whittier. 2014. Effect of the first GnRH and two doses of PGF2 $\alpha$ in a 5-day progesterone-based CO-Synch protocol on heifer pregnancy. Theriogenology 81:797-804. http:// dx.doi.org/10.1016/j.theriogenology.2013.12.023

Kasimanickam, R., M. Asay, P. Firth, W. D. Whittier, \& J. B. Hall. 2012. Artificial insemination at $56 \mathrm{~h}$ after intravaginal progesterone device removal improved AI pregnancy rate 
in beef heifers synchronized with five day CO-Synch controlled internal drug release (CIDR) protocol. Theriogenology 77:1624-31. http://dx.doi.org/10.1016/j.theriogenology.2011.12.007

Keskin, A., G. Yilmazbas-Mecitoglua, A. Gumena, E. Karakayaa, R. Daricib, \& H. Okutc. 2010. Effect of hCG vs. GnRH at the beginning of the Ovsynch on first ovulation and conception rates in cyclic lactating dairy cows. Theriogenology 74:602-607. http://dx.doi.org/10.1016/j.theriogenology.2010.03.009

Kim, U. H., G. H. Suh, H. W. Nam, H. G. Kang, \& I. H. Kim. 2005. Follicular wave emergence, luteal function and synchrony of ovulation following GnRH or estradiol benzoate in a CIDR-treated, lactating Holstein cows. Theriogenology 63: 260-268. http://dx.doi.org/10.1016/j.theriogenology.2004.04.005

Lee, S. M., M. S. Rahman, W. S. Kwon, H. J. Chung, B. S. Yang, \& M. G. Pang. 2013. Efficacy of four synchronization protocols on the estrus behavior and conception in native Korean cattle (Hanwoo). Theriogenology 80:855-861. http:// dx.doi.org/10.1016/j.theriogenology.2013.07.010

Lima, F. S., H. Ayres, M. G. Favoreto, R. S. Bisinotto, L. F. Greco, \& E. S. Ribeiro. 2011. Effects of gonadotropinreleasing hormone at initiation of the 5-d timed artificial insemination (AI) program and timing of induction of ovulation relative to AI on ovarian dynamics and fertility of dairy heifers. J. Dairy. Sci. 94:4997-5004. http://dx.doi. org/10.3168/jds.2011-4240

Martins, T., R. F. G. Peres, A. D. P. Rodrigues, K. G. Pohler, M. H. C. Pereira, M. L. Day, \& J. L. M. Vasconcelos. 2014. Effect of progesterone concentrations, follicle diameter, timing of artificial insemination, and ovulatory stimulus on pregnancy rate to synchronized artificial insemination in postpubertal Nellore heifers. Theriogenology 81: 446-453. http://dx.doi.org/10.1016/j.theriogenology.2013.10.020

Meneghetti, M., O. G. Sa' Filho, R. F. G. Peres, G. C. Lamb, \& J. L. M. Vasconcelos. 2009. Fixed-time artificial insemination with estradiol and progesterone for Bos indicus cows I: Basis for development of protocols. Theriogenology 72: 179189. http://dx.doi.org/10.1016/j.theriogenology.2009.02.010

Nuryadi \& S. Wahjuningsih. 2011. Penampilan reproduksi sapi peranakan ongole dan peranakan limousin di Kabupaten Malang. J. Ternak Tropika 12: 76-81, 2011

Patterson, D. J., F. N. Kojima, \& M. F. Smith. 2003. A review of methods to synchronize estrus in replacement beef heifers and postpartum cows. J. Anim. Sci. 81:166-177.

Perez, R. F. G., G. Júnior, O. G. Sá Filho, G. P. Nogueira \& J. L. M. Vasconcelos. 2009. Strategies to improve fertility in Bos indicus postpubertal heifers and nonlactating cows submitted to fixed-time artificial insemination. Therio- genology 72:681-9. http://dx.doi.org/10.1016/j.theriogenology.2009.04.026

Peterson, C., A. Alkar, S. Smith, S. Kerr, J. B. Hall, \& D. Moore. 2011. Effects of one versus two doses of prostaglandin F2alpha on AI pregnancy rates in a 5-day, progesteronebased, CO-Synch protocol in crossbred beef heifers. Theriogenology 75:1536-42. http://dx.doi.org/10.1016/j.theriogenology.2010.12.017

Ramana, K. V., K. V. Rao, K. Supriya, \& N. Rajanna. 2013. Postpartum ovarian follicular dynamics and estrus activity in lactating Ongole cows. J. Res. Angrau. 41: 51-55.

Sahu, S. K., J. F. Cockrem, T. J. Parkinson, \& R. A. Laven. 2014. The effects of exclusion of progesterone or Day $0 \mathrm{GnRH}$ from a $\mathrm{GnRH}$, prostaglandin, $\mathrm{GnRH}+$ progesterone program on synchronization of ovulation in pasture-based dairy heifers. Theriogenology 82:643-651. http://dx.doi. org/10.1016/j.theriogenology.2014.06.004

Sá Filho, M. F., H. Ayres, R. M. Ferreira, M. Marques, E. L. Reis, R. C. Silva, C. A. Rodrigues, E. H. Madureira, G. A. Bó, \& P. S. Baruselli. 2010. eCG and GnRH enhance fertility in a norgestomet-based, timed AI protocol in suckled Nelore (Bos indicus) cows. Theriogenology 73: 651-658. http://dx.doi.org/10.1016/j.theriogenology.2009.11.004

Sartori, R. \& C. M. Barros. 2011. Reproductive cycles in Bos indicus cattle. Anim. Reprod. Sci. 124: 244-250. http://dx.doi. org/10.1016/j.anireprosci.2011.02.006

Sartori, R. P., M. Fricke, J. C. Ferreira, O. J. Ginther, \& M. C. Wiltbank. 2001. Follicular deviation and acquisition of ovulatory capacity in bovine follicles. Biol. Reprod. 65:14031409. http://dx.doi.org/10.1095/biolreprod65.5.1403

Souza, A. H., H. Ayres, R. M. Ferreira, \& M. C. Wiltbank. 2008 A new presynchronization system (Double-Ovysnch) increases fertility at first postpartum timed $\mathrm{AI}$ in lactating dairy cows. Theriogenology 70:208-15. http://dx.doi. org/10.1016/j.theriogenology.2008.03.014

Twagiramungu, H., L. A. Guilbault, \& J. J. Dufour. 1995. Synchronization of ovarian follicular waves with a gonadotropin-releasing hormone agonist to increase the precision of estrus in cattle: a review. J Anim Sci.73:3141-51.

Whittier, W. D., R. K. Kasimanickam, J. F. Currin, H. H. Schramm, \& M. Vlcek. 2010. Effect of timing of second prostaglandin F 2 alpha administration in a 5-day, progesterone-based CO-Synch protocol on AI pregnancy rates in beef cows. Theriogenology 74:1002-9. http://dx.doi. org/10.1016/j.theriogenology.2010.04.029

Wiltbank, M. C. \& J. R. Pursley. 2014. The cow as an induced ovulator: Timed AI after synchronization of ovulation. Theriogenology 81:170-185. http://dx.doi.org/10.1016/j. theriogenology.2013.09.017 